American Journal of Environmental Sciences 4 (6): 701-709, 2008

ISSN $1553-345 \mathrm{X}$

(C) 2008 Science Publications

\title{
Contribution to the Study of the Origin of Salinity in Alluvial Aquifer System in the Ain Chabro-Hammamet (North-East ALGERIA)
}

\author{
${ }^{1} \mathrm{~K}$. Seghir and ${ }^{2}$ N. Khérici \\ ${ }^{1}$ Department of Sciences of the Earth and of Town and Country Planning University of Tebessa, Algeria, LTHE, \\ Laboratory of Study of the Transfers in Hydrology and Environment, House of the Geosciences 1381 Street of \\ Swimming 38.400 Saint Martin d' Heres, Grenoble, France \\ ${ }^{2}$ Faculty of Science of the Earth, University Badji Mokhtar, Annaba, Algeria
}

\begin{abstract}
Tebessa is located in the Algerian North East. It is characterized by a semi-arid continental climate with an average interannual precipitation of less than $400 \mathrm{~mm}$. It belongs to the Eastern Saharian Atlas field along the Tunisian borders. It is drained by a certain number of the wouady of which Chabro and Bouakous are the most important. The surface area of the region extends over $420.6 \mathrm{~km}^{2}$. Problem statement: This region has been a very intense drought during the last 20 years (1980/2000). This drought has generally led to: a general lowering of the water table; the draining water from low depth wells; in particular, the unwatering of the pumping equipment, involving a reduction of the flow drillings and the drying-up of the natural springs. Approach: Therefore, the quantitative and qualitative repercussions were shown on groundwater resources in the area. Four sampling of two years $(2005,2006)$ has been realized during the high and low waters period. The chemical analysis and the piezometric measures have been done to raise up representative quality and the chart piezometric of the current water table state. Results: The hydro-chemical survey of the groundwater quality, as well as its evolution in the time and the space is become very necessary; especially when the water was destined to the supply of drinking water is continuously deteriorating. It was proved that, the salinity was about $4 \mathrm{~g} \mathrm{~L}^{-1}$, and the electric conductivity was varied between (997$9120 \mu \mathrm{S} \mathrm{cms}{ }^{-1}$ in the wells and $468-2500 \mu \mathrm{S} \mathrm{cms}^{-1}$ in drillings). Conclusions: Thus, the results were obtained shows that, the origin of water salinity were associated to the dissolution of geological formations (evaporate and carbonated), as well as the effects of anthropogenic surface pollution.
\end{abstract}

Key words: Drought, Salinity, basic exchange, pollution, index of saturation

\section{INTRODUCTION}

In the Mediterranean areas, the salinity of the underground water constitutes one of the most extensive problems these last years; because of its negative effects on the quality of the water and the decreasing of the agricultural productions. It is often linked to the nature of the geological formations, the long-standing drought and the effect of the evaporation $^{[4,7-10,12,13]}$. The study area is situated in the northwest extremity of the city Tebessa (NE.Algerian). It belongs to the Eastern Saharian Atlas area along the Tunisian borders. It is located within the following geographical coordinates: (longitude $7^{\circ} 50^{\prime}-8^{\circ} 10^{\prime}$ East, Latitude $35^{\circ} 24^{\prime}-35^{\circ} 35^{\prime}$ North). It is drained by a certain number of the wouady of which Chabro and Bouakous are the most important. The surface area of the region extends over $420.6 \mathrm{~km}^{2}$, with a total population about 194000 inhabitants, distributed in the many villages and agglomeration (Fig. 1). It is characterized by a semi-arid continental climate with an average interannual precipitation of less than $400 \mathrm{~mm}$. The calculation of the water balance using Thornthwaite's method shows that, the Evapotranspiration Effect (EET) consume all precipitations; practically with the values of water deficit is about $545.5 \mathrm{~mm}$. The rain wash and the seepage water are negligible of the order of $16,6 \mathrm{~mm} \mathrm{(4,}$ $5 \%$ total precipitations). From the geological point of view, the study area is the part of the fault basin Tebessa/Morsott/Hammamet. It is filled with the sediments of continental origin, with the most important hydrodynamic characteristics $(\mathrm{K}, \mathrm{T}, \mathrm{S} \ldots)$. It consists of stratigraphic series from the Trias to the Quaternary,

Corresponding Author: K. Seghir, Department of Sciences of the Earth and of Town and Country Planning, University of Tebessa, Algeria, LTHE, Laboratory of Study of the Transfers in Hydrology and Environment,

House of the Geosciences 1381 Street of Swimming 38.400 Saint Martin d' Heres, Grenoble, France 


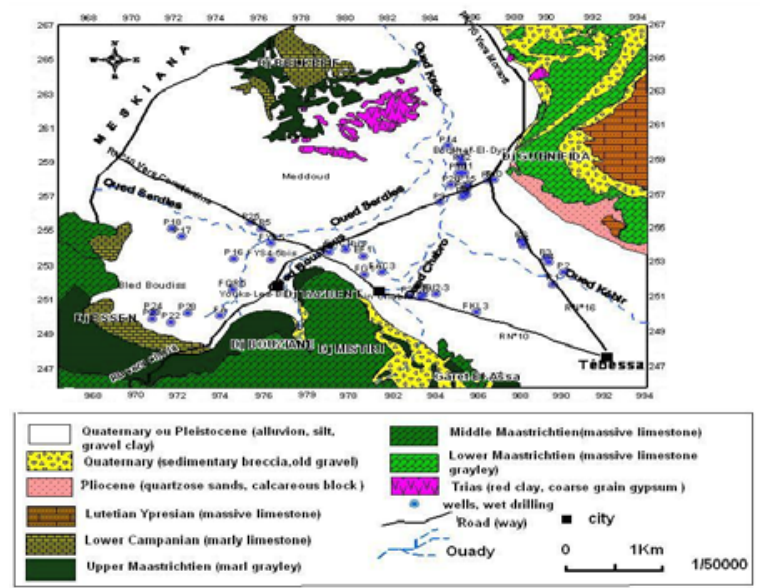

Fig. 1: Localization of the points of water and the geological context of the survey region

including several aquiferous formations, thus, one of the most important are the Mæstrichtien dated (limestone fissured in borders), and alluvial deposits in the plain. These formations are due to the Mio-Pliocene age which that constituted by the gravel calcareous envelopes, more or less, in a clayey matrix, with a thickness more $350 \mathrm{~m}$ in some zones. The alluvial water table is composed of sands, gravels, clays and gypseous marls. The Triassic formations appear on the surface of the eastern part of the Djebissa mountain and in the West North of the Belkfif mountain. The soil permeability varies from $10^{-2}-10^{-3} \mathrm{~m} \mathrm{sec}^{-1}$ and its transmissivity oscillates between $10^{-3}$ and $10^{-4} \mathrm{~m}^{2}$ $\sec ^{-1[11,12,13]}$. The output flow from the 23 drilling which adjoins of $356 \mathrm{~L} \mathrm{sec}^{-1}$.

On the hydrodynamic plan, the piezometric measures which has been done during the years 2004, 2005,2006 , shows that, the piezometric surface depth is very variable in the space and in the time in relation to the surface of the soil. The static level varies between 1 , 5 and $25 \mathrm{~m}$ in high water and 9-45 $\mathrm{m}$ in low water. The impact of drought in the last twenty years (1980-2000) was very negative, when we emphesize a significant decrease in the piezometric levels (Fig. 2). The underground water of the Tebessa-Hammamet plain is known with a large spatial variation of the salinity from a maximum of $4 \mathrm{~g} \mathrm{~L}^{-1}$ and electrical conductivity is estimated the total mount of the dissolved salts, to vary from $468-9120 \mu \mathrm{Sms}^{-1}$. The origin of water salinity is depends on two chemical elements groups. They are: The saliferous elements $\left(\mathrm{SO}_{4}{ }^{2-}, \mathrm{Na}^{+}\right.$and $\left.\mathrm{Cl}^{-}\right)$and the carbonated elements $\left(\mathrm{Ca}^{2+}, \mathrm{Mg}^{2+}\right.$ and $\left.\mathrm{HCO}_{3}{ }^{-}\right)$. The objectives of the study are to find out the origin of the chemical elements and its evolution in the time and in the space, and to evaluate the different hydro geochemical processes which developed in alluvial plain.

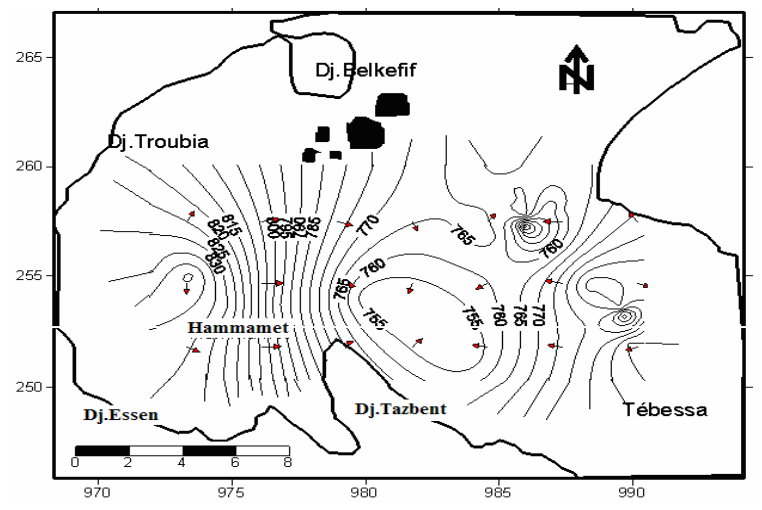

Fig. 2: Piezometric card (May 2006) the geological context of the survey region

\section{MATERIALS AND METHODS}

Forty two wells and drillings have been made the object of the following chemical composition of the water $\left(\mathrm{Ca}^{2+}, \mathrm{Mg}^{2+}, \mathrm{Na}^{+}, \mathrm{K}^{+}, \mathrm{Cl}^{-}, \mathrm{SO}_{4}{ }^{2-}, \mathrm{HCO}_{3}^{-}, \mathrm{NO}_{3}{ }^{-}\right.$, $\left.\mathrm{Sr}^{2+}\right)$. The physico-chemical parameters $\left(\mathrm{pH}, \mathrm{T}^{\circ} \mathrm{C}\right.$, conductivity, TDS, Salinity, and $\mathrm{O}_{2}$ ) were measured in the place of study with the aid of an equipment of 340iWTW type. Concerning the determination of major elements: the water samples were taken in new plastic bottles (polyethylene) and were filtred with a sterile syringe filters of $45 \mu \mathrm{m}$; those intended to cations them were acidified at $\mathrm{pH}<2$. The samples were preserved immediately in a refrigerator at a temperature of less than $4^{\circ} \mathrm{C}$, and were sent directly to the Laboratory of the University of Geneva (Switzerland), for the analysis by ICP-MS of cations and trace elements. While the anions, were determined by chromatography method in Laboratory (LGIT) of University Joseph Fourier, France. The analysis of bicarbonates $\left(\mathrm{HCO}_{3}{ }^{-}\right)$; the title alkalimeter (TA, TAC) and total hardness $\left(\mathrm{DH}^{\circ}\right)$ were prepared by volumetry method in the Laboratory of Earth Sciences institute of Tebessa University (Algeria $)^{[12]}$. Four phases piezometric has been realized in parallel at the High and Low water periods (2005, 2006).

\section{RESULTS AND DISCUSSION}

Evolution of the chemical elements: The results obtained watch that: The electric conductivity values raises between $997-9120 \mu \mathrm{S} \mathrm{cms}^{-1}$ in the well and 468$2500 \mu \mathrm{S} \mathrm{cms}^{-1}$ in the drilling associated with increased salinity reaching a maximum value of $4 \mathrm{~g} \mathrm{~L}^{-1}$. The spatial-temporal evolution of the chemical elements allowed to distinguish: 
- The calcium and magnesium elements have been a minimal and maximal contents, respectively of 100.99 and $398.99 \mathrm{mg} \mathrm{L}^{-1}$ for the calcium, and of 29.81 and $491.38 \mathrm{mg} \mathrm{L}^{-1}$ for the magnesium

- For sodium and chloride, the minimal contents are recorded in the west part of region in the $\mathrm{P}_{21}$ and $\mathrm{P}_{23}$ well, for chloride $\left(75.74 \mathrm{mg} \mathrm{L}^{-1}\right.$ ) and $\mathrm{P}_{3}$ well for sodium $\left(65.99 \mathrm{mg} \mathrm{L}^{-1}\right)$. The maximum chlorides concentrations were recorded at the $\mathrm{P}_{1}$ well with the value of 795.94 and $600.8 \mathrm{mg} \mathrm{L}^{-1}$ for sodium. The distribution of these two elements is well correlated with the electric conductivity (Fig. 3). The highest values are observed in the center and north of the plain, in relation with Triassic saliferous lands present in the Belkfif feet mountain

The sulphate concentration varies between a minimum of $138.2 \mathrm{mg} \mathrm{L}^{-1}\left(\mathrm{P}_{21}\right)$ and a maximum of $1462 \mathrm{mg} \mathrm{L}^{-1}\left(\mathrm{P}_{20}\right)$. The weakest contents were observed in the Hammamet zone in the west part of plain. Then, they have the tendency to increase in the East and the Southwest progressively northwards in the Ain Chabro zone. The origin of sulphate would be the rain water washing of evaporates formations (gypsum and anhydrites) and superficial formations rich in clays and marls.

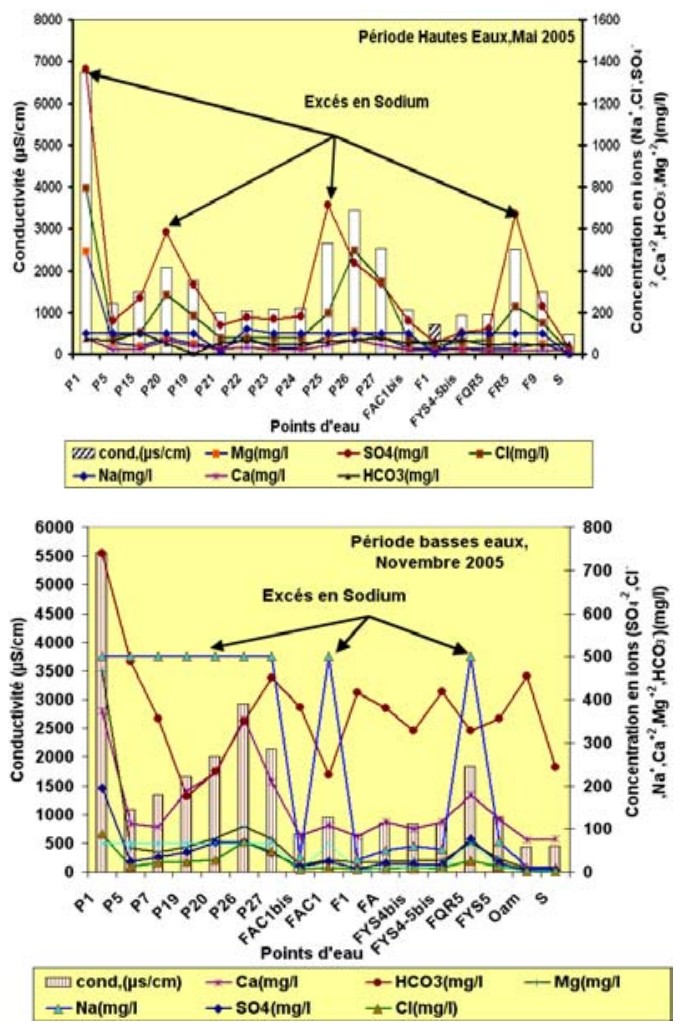

Fig. 3: Evolution chemical elements
For carbonates, the concentrations vary between a smallest of $130.42 \mathrm{mg} \mathrm{L}^{-1}\left(\mathrm{P}_{19}\right)$ and a highest of $740.54 \mathrm{mg} \mathrm{L}^{-1}\left(\mathrm{P}_{1}\right)$. The increase contents were observed in the Ain Chabro zones near the borders west southern and in the Hammamet region, showing an exchange with the Cenomanien carbonated lands.

For potassium, this element participates very little in the water mineralization. The minimal and maximal concentrations are respectively of $0.25 \mathrm{mg} \mathrm{L}^{-1}\left(\mathrm{P}_{1}\right)$ and $2.26 \mathrm{mg} \mathrm{L}^{-1}\left(\mathrm{P}_{20}\right)$.

Dominant chemical facies: The quality of groundwater show two dominant chemical facies: sodium chloride, and calcic sulphate (Fig. 4). It has been observed in the centre of plain and the northern part. Seen that, the proximity of water points to the Triassic outcrops of Belkefif Mountain, the influence of Triassic saliferous lands, rich in halite, is strongly smelled. While the upstream toward moving away, along the National road $10 \mathrm{~N}^{\circ}$ in the plain west part, the Trias influence absorbs and the facies become rather bicarbonate or sulphate calcic and soda, translating the matrix carbonated borders west south influence, that constitutes a limit to flow incoming (natural refill by the meteoric waters).

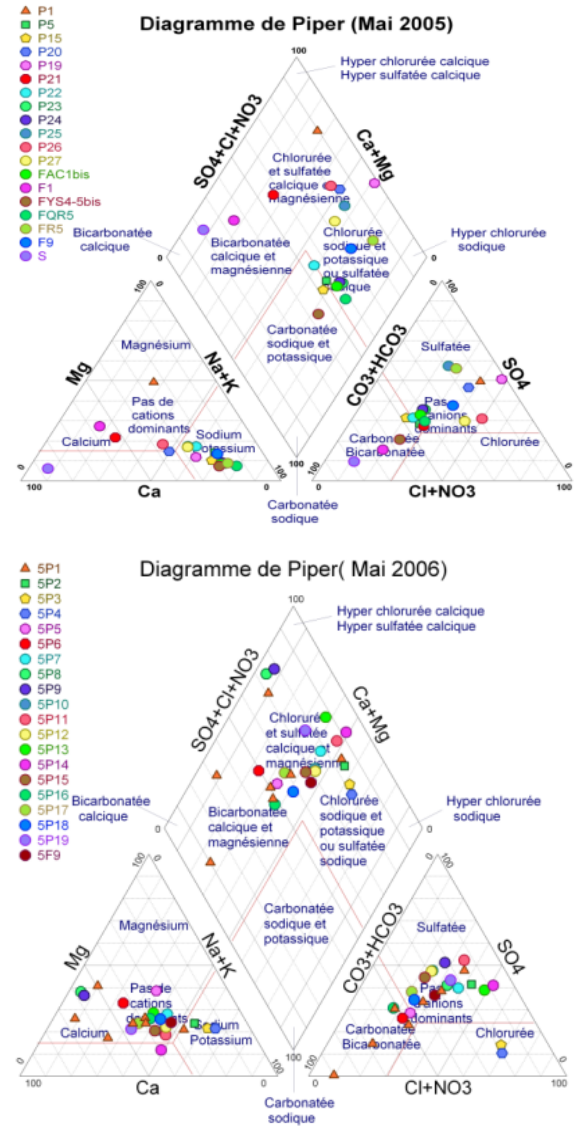

Fig. 4A: Piper diagrams representation 
Am. J. Environ. Sci., 4 (6): 701-709, 2008

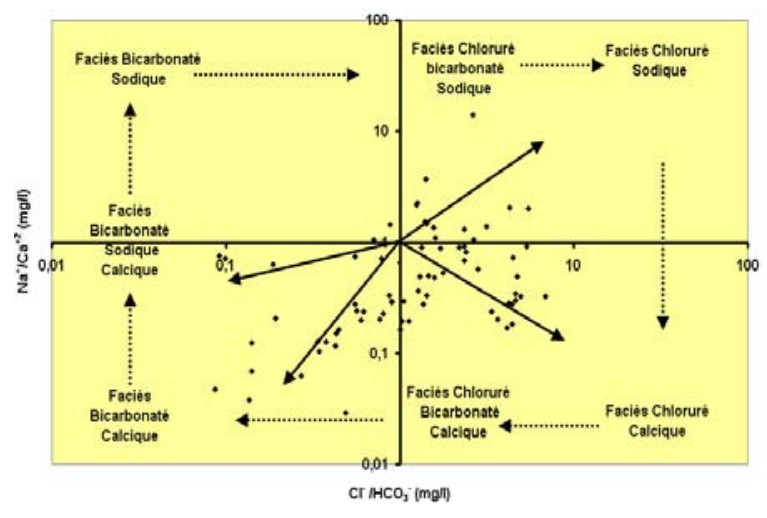

Fig. 4B: Diagram of dominant chemical facies

Principal Component Analysis (PCA): To confirm our previous interpretation, the statistical analysis has been achieved with the use of Hydro Aqua software (VALLES VINCENT, Laboratory of Hydrogeological at the University of Avignon; 2007). The distribution inertias watch a variance axis main of $41 \%$. Come then, two other sources of variability with equal importance (respectively 13 and $12 \%$ for variance). The projection of variables on plane I-II shows two poles:

The first factorial axis: Oppose the minor elements as $\mathrm{Ba}$, Min., $\mathrm{K}^{+}, \mathrm{O}_{2}, \mathrm{Zn}^{+2}, \mathrm{pH}$ to the soluble major elements: CE (conductivity), salinity, TDS, $\mathrm{Mg}^{+2}$. The little soluble elements major in an residual alkalinity negative environment (as $\mathrm{HCO}_{3}{ }^{-}$) were in intermediate position. This first axis is frequent enough the hydrochemical of Mediterranean and tropical region. It is about the salinity. He translated the variation of chemical composition when the water salting; that means, when their mineralization were increased.

The second factorial axis: Oppose the oxygen, $\mathrm{pH}$ to the nitrates and potassium (as well as some metals). This is the axis of ventilation, but also an axis representing probably the agricultural activity (positive correlation $\mathrm{K} / \mathrm{NO}_{3}$ that means fertilization). The aired water is usually poor in $\mathrm{CO}_{2}$ from where an elevated $\mathrm{pH}$ (positive correlation between $\mathrm{O}_{2}$ and $\mathrm{pH}$ on this factorial axis). The nitrates position cannot explain itself here that by the denitrification process. Indeed, the negative relationship nitrates $/ \mathrm{O}_{2}$ is incompatible with this process. It agrees to integrate the agricultural aspects (Fig. 5A and B).

The origin of chemical elements study: One verifies here the geological origin of chemical elements from the good interrelationship that exists between them. Two main relations will be examined.
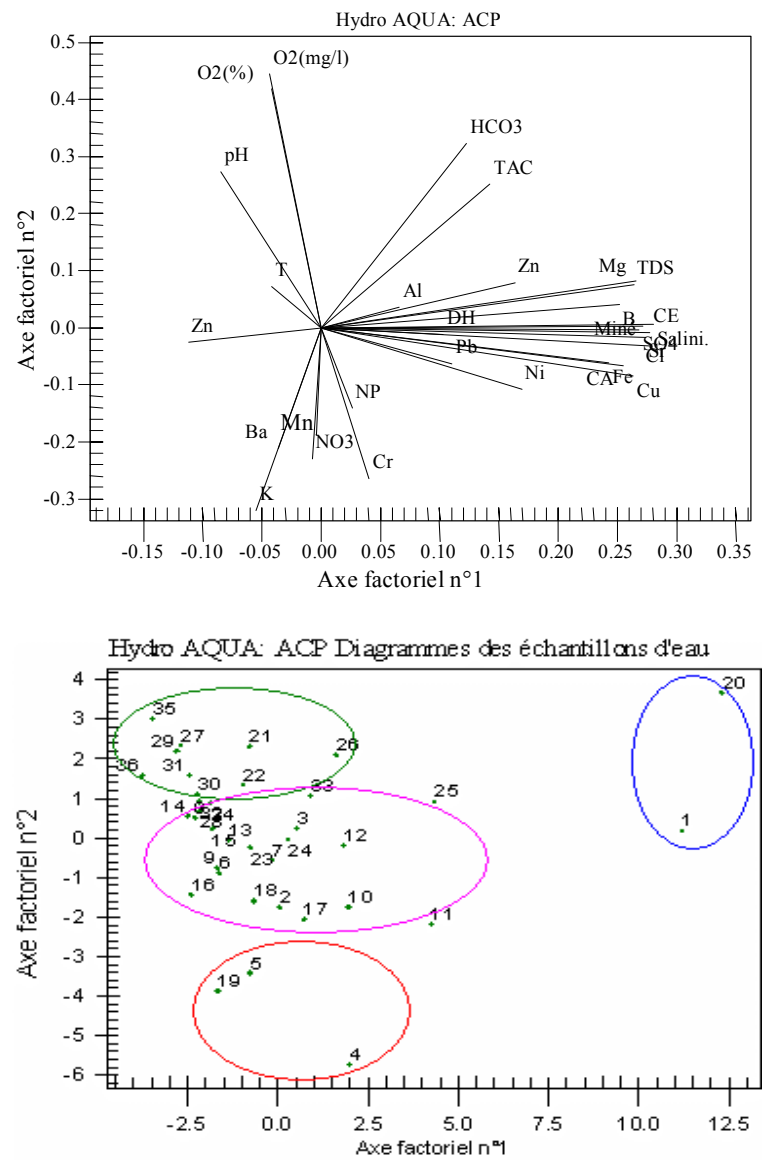

Fig. 5A: Individual projection on the plane I-II

The $\mathrm{Na}^{+} / \mathrm{Cl}^{-}$couple: In natural waters these two chemical elements are often connected to halite $(\mathrm{NaCl})$ dissolution. The evolution of $\mathrm{Na}^{+}$is studied according to the chlorides contents, because this last, is considered as a steady tracer and conservative of the very soluble evaporates; rarely incoming in saline precipitation, and not intervening in the oxidation-reduction phenomena, and little influenced by the bacteria intervention ${ }^{[7-9,11-13]}$. The evolution graphic representation (Fig. 6), watch two processes.

- For the strong concentrations of chlorides, one observes a direct relation between $\mathrm{Na}^{+}$et $\mathrm{Cl}^{-}$, indicating that a common origin of these two chemical elements

For the weak concentrations of chlorides, one observes a constant excess of sodium contents, it explains itself by another origin of the ion of soda that made increase the concentration of sodium. 

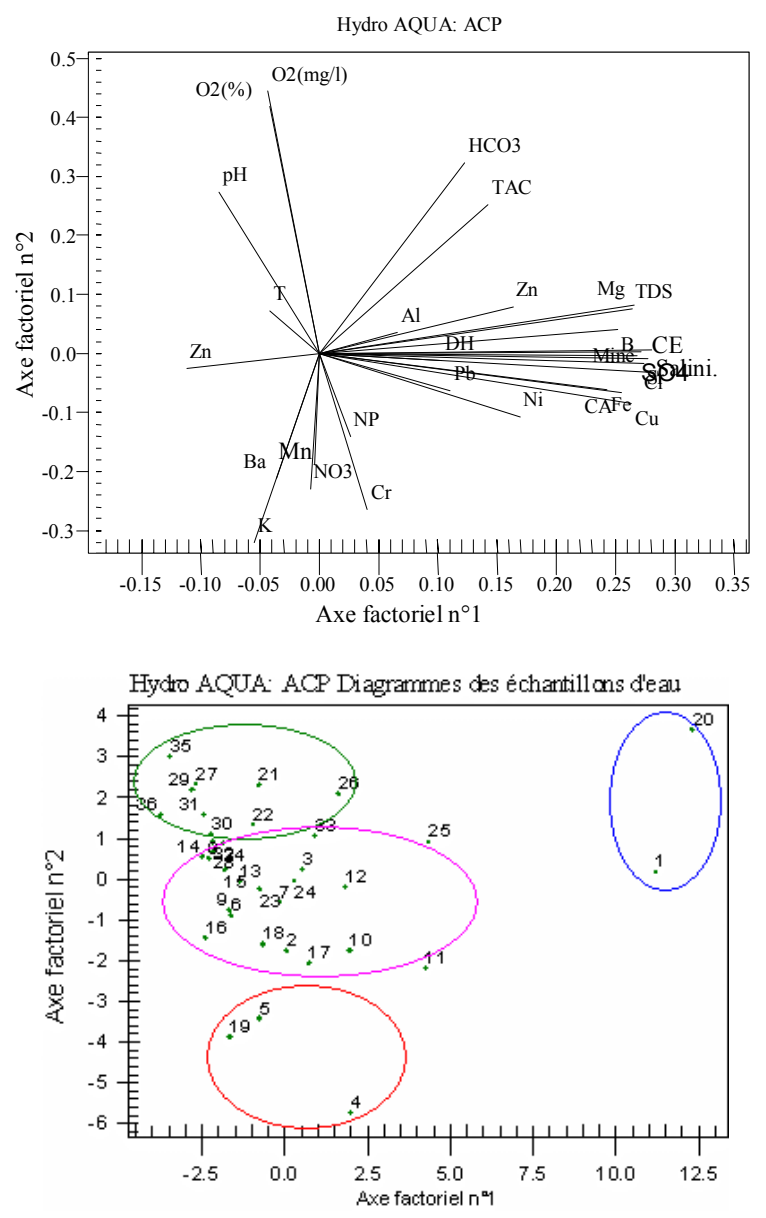

Fig. 5B: Individual Projection on the plane I-III Principal Components Analysis (PCA)

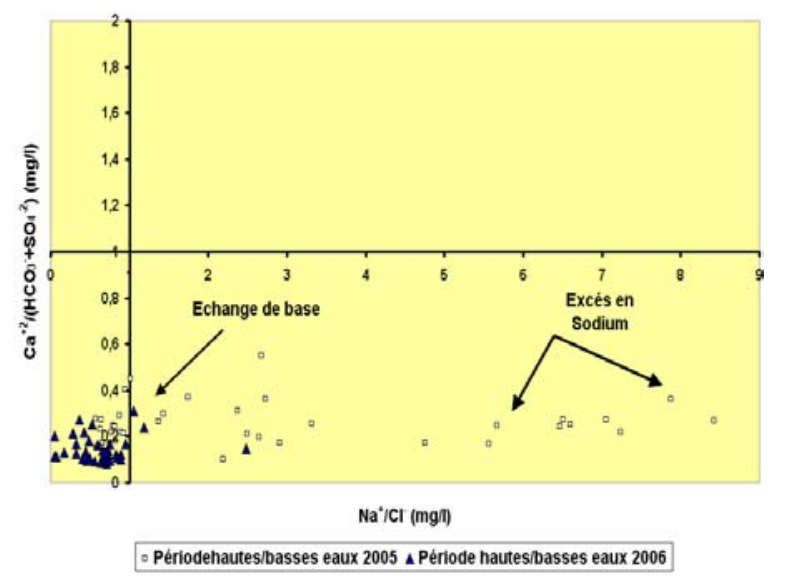

Fig. 6: Basis exchange

This contribution supplementary could come from the alteration of soda silicates (Clays). But since, this excess of $\mathrm{Na}^{+}$was come with a deficit of $\mathrm{Ca}^{2+}$ in relation to $\mathrm{HCO}_{3}{ }^{-}$and $\mathrm{SO}_{4}{ }^{2-}$ (Fig. 6B), the increase of $\mathrm{Na}^{+}$contents cannot explain itself that by an basis exchange related to the clayey minerals. This last fixes an ion of $\mathrm{Ca}^{2+}$ after liberation of two ions of $\mathrm{Na}^{+}$. The $\mathrm{Ca}^{2+} /\left(\mathrm{HCO}_{3}{ }^{-}+\mathrm{SO}_{4}{ }^{2-}\right)-\mathrm{Na}^{+} / \mathrm{Cl}^{-}$diagram watch that $75 \%$ of the water points submit to an basis exchange, $10 \%$ of the point present the natural state and $15 \%$ an excess in $\mathrm{Ca}^{2+}$ in relation to the $\mathrm{HCO}_{3}{ }^{-}$ions- and $\mathrm{SO}_{4}{ }^{2-}$ due surely to the gypseous formations that provide more ions of $\mathrm{Ca}^{2+}$.

Origin of calcium: One examines here the origin of calcium to according with two chemical elements $\left(\mathrm{HCO}_{3}^{-}, \mathrm{SO}_{4}{ }^{-2}\right)$ that indicates his two main origins (carbonates and gypsum) (Fig. 7). The graphic (Fig. 7A) show a set of points those positions to according to only one grouping, indicating the carbonated origin of the calcium ions, and the exponential evolution of these two elements. To determine the evolution of calcium according to elements $\left(\mathrm{HCO}_{3}^{-}, \mathrm{SO}_{4}^{-2}\right)$, a graphic (Fig. $7 \mathrm{~B}$ ) made appear two evolutions: the excess exponential of $\mathrm{Ca}^{2+}$ indicating the origin evaporates by gypsum of $\mathrm{Ca}^{2+}$ and on the other hand, one observes an inverse evolution interpreted as the result of dissolution of the carbonated formations. These two representations show us that the dissolution of calcium ions from the carbonated formations is more important and that, the strong concentrations of $\mathrm{Ca}^{2+}\left(>250 \mathrm{mg} \mathrm{L}^{-1}\right)$ were related more to the dissolution of evaporates formations (gypsum).

Characteristic reports: We apply the characteristic reports that are used to determine the chemical evolution of the elements.

The $\mathrm{Cl}^{-} / \mathrm{SO}_{4}{ }^{2-}$ electric conductivity relationship: This report allowed determining the manner according to which evolves the ions evaporates dissolution according to the Conductivity $\left(\mathrm{Na}^{+}\right.$marker of the halite and $\mathrm{SO}_{4}{ }^{2-}$ marker of gypsum). It watch the lower values of 1 in the majority of the water points indicating an underground water enrichment in sulphates ions in all the aquiferous, with the exception of the wells $\left(\mathrm{P}_{26}, \mathrm{P}_{27}\right)$ in the north plain where the report reaches some higher values of 1 , what constitutes a raised rate of chlorides. The increases of chlorides content in toward the East were observed in relation with the remoteness of Triassic saliferous lands; who's his influence is marked more in the west and North West of plain. This increase able to explain, itself that, by the effect of anthropogenic surface pollution (often the effect of the waste waters) (Fig. 8A). 
Am. J. Environ. Sci., 4 (6): 701-709, 2008
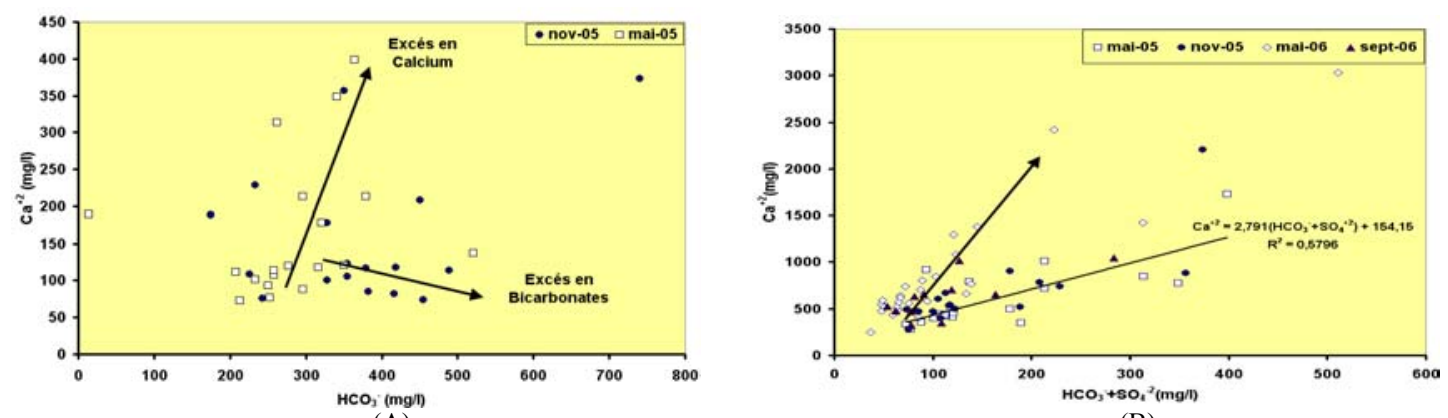

(B)

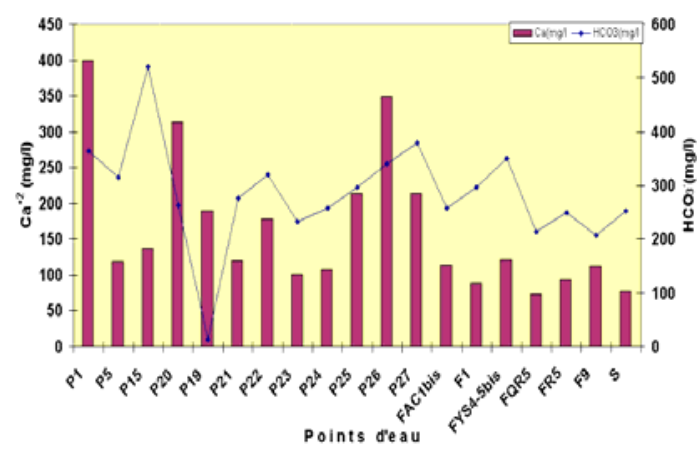

(C)

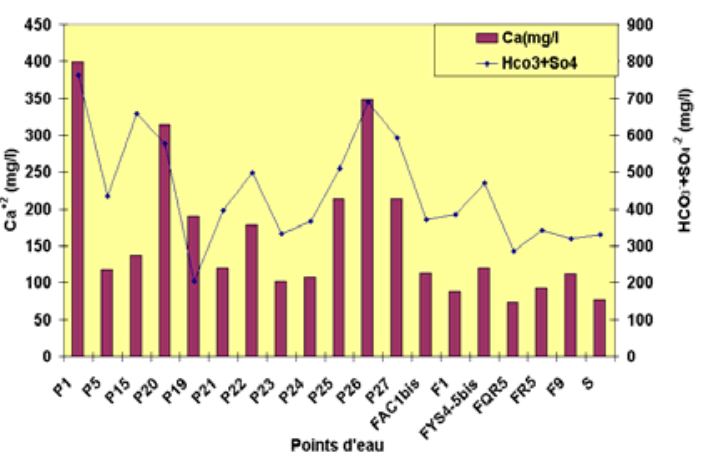

(D)

Fig. 7(A, B, C and D): Origin of calcium

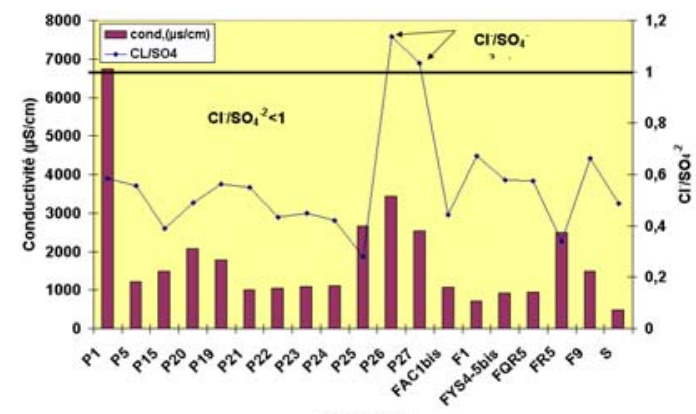

(A)

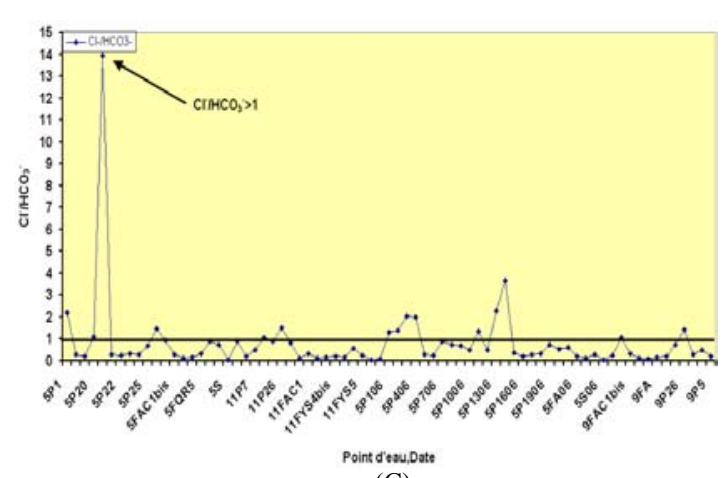

(C)

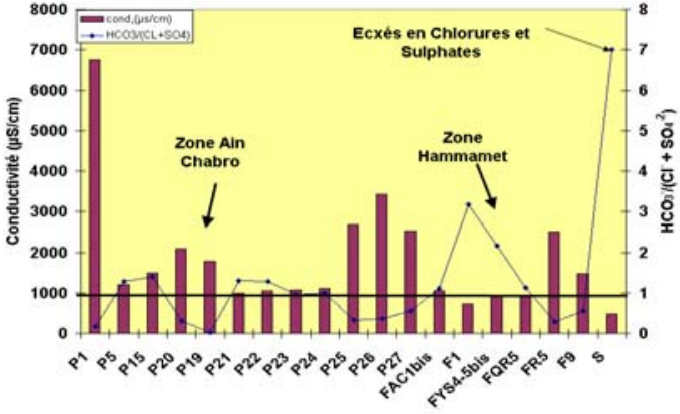

(B)

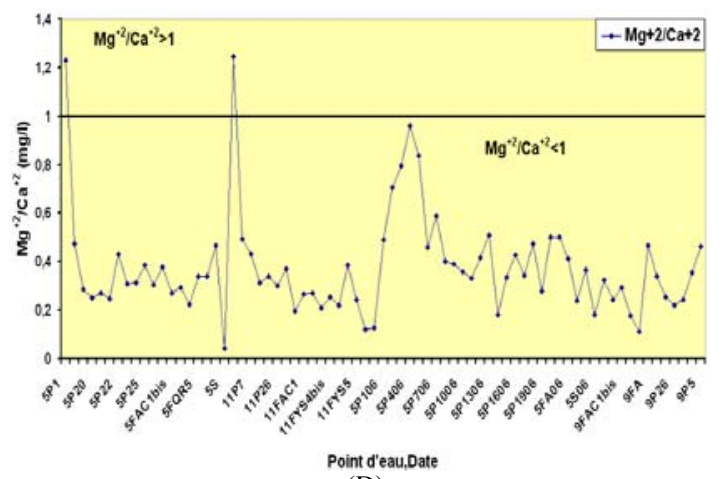

(D)

Fig. 8(A, B, C and D): Characteristics reports 
The $\mathrm{HCO}_{3}{ }^{-} /\left(\mathrm{Cl}^{-}+\mathrm{SO}_{4}{ }^{2-}\right)$-electric conductivity relationship: We note here an inverse relation between the $\mathrm{HCO}_{3}{ }^{-} /\left(\mathrm{Cl}^{-}+\mathrm{SO}_{4}{ }^{2-}\right)$ report and the conductivity. The reduction of report $(r<1)$ has been accompanied by an increase in conductivity values because the excess in $\left(\mathrm{SO}_{4}{ }^{2-}, \mathrm{Cl}^{-}\right)$ions. It has been noted especially in the depth weak of wells and that existed in the center and north plain. On the other hand, the increase of the report of $\mathrm{HCO}_{3}{ }^{-} /\left(\mathrm{Cl}^{-}+\mathrm{SO}_{4}{ }^{2-}\right)(\mathrm{r}>1)$ in some water points notably with a big depth $(>60 \mathrm{~m})$ to explain with an excess in the ions of bicarbonates with a middle or weak conductivity $\left(<1000 \mu \mathrm{S} \mathrm{cm} \mathrm{cm}^{-1}\right)$. By consequence, two poles were observed: one is carbonated characterized by the dominance of $\mathrm{HCO}_{3}^{-}$ions and conductivity lower than $1000 \mu \mathrm{S} \mathrm{cm} \mathrm{cm}^{-1}$. The other is evaporated, and it assured the dominance of $\mathrm{Cl}^{-}$and $\mathrm{SO}_{4}{ }^{2}$-ions . This pole appear for the strong conductivity $\left(>1000 \mu \mathrm{S} \mathrm{cm}^{-1}\right)$ and to gather the majority waters points in the center of plain. These graphs reveal that a weak values of conductivity $\left(<1000 \mu \mathrm{S} \mathrm{cm} \mathrm{cm}^{-1}\right)$, where there is not evaporates formations, is bound to the ions of bicarbonates. On the other hand when, the conductivity passes through a maximum value of 2000 $\mu \mathrm{S} \mathrm{cm}^{-1}$ it becomes allied more to the evaporates ions $\left(\mathrm{Cl}^{-}\right.$and $\left.\mathrm{SO}_{4}{ }^{2-}\right)$ (Fig. 8B).

The $\mathrm{Mg}_{2}{ }^{+} / \mathrm{Ca}_{2}{ }^{+}$report: It also show that some values lower to 1 indicating the predominance of calcium ions, except in the well $\left(\mathrm{P}_{1}\right)$ where the report is superior to 1 , what translates the influence of chalky matrix on the one dolomitic at the outcrops level of the aquiferous in the west south borders. It is the result of water undersaturation by calcite. Besides, the lower report could be the origin evaporates related to magnesium (Fig. 8D).

The $\mathrm{Cl}^{-} / \mathrm{HCO}_{3}{ }^{-}$report: It shows that some of the values lower to 1 in the northwest and the west of the Triassic saliferous lands, translating that the predominance of the bicarbonates ions. While moving away toward the East, this report has a tendency to rise to become superior to 1 in relation with the influence of Cenomanien lands, notably in wells $\left(\mathrm{P}_{1}, \mathrm{P}_{19}, \mathrm{P}_{26}\right.$, and $\mathrm{P}_{20}$ ) situated in the center of plain and in Ain chabro zone.

The minerals evolution and the dissolved elements survey: The saturation index of the dissolved mineral has been calculated using the Debye-Huckel law. The mineral have been distributed in two groups.
The carbonates group present different degrees of saturation according to high and low water period: The dolomite is often in the oversaturation state, with an index that varies between 2,11 and -2,66. This last followed by the calcite and the aragonite minerals with an saturation index that varies between 1,21-1,14 and 1,06-1,29 indicating a some variation between undersaturation and oversaturation state. The Spatial distribution of every chemical element shows that the high concentration are observed either close to the Belkfif mountain and in the Ain chabro zone in center of plain, either in the evaporates zones that provides the ions of $\mathrm{Ca}^{2+}$ and $\mathrm{Mg}^{2+}$ These last are going to combine themselves with the atmosphere $\mathrm{CO}_{2}$ to give some carbonated mineral.

The evaporate group is under saturated in relation with the anhydrite, gypsum, with index varying between $(-0,63 \quad-2,36, \quad-0,38 \quad-2,11, \quad-5,08 \quad-8,64)$ respectively. The increase of evaporates mineral saturation index was observed itself in the plain close to the evaporate lentils. They indicate that only the carbonated minerals have been the tendency to precipitate as calcite and dolomitic, especially during the High waters period. On the other hand, the evaporate minerals are always the under-saturation state, even the ions of $\mathrm{Na}^{+} \mathrm{Cl}^{-}$and $\mathrm{SO}_{4}{ }^{2-}$ they have a strong concentration in the water. That is explained by elevated values of the constant of evaporate minerals balance $\left(\mathrm{NaCl}(1,58), \mathrm{CaSO} 4(-4,85)^{[8,9,12]}\right.$, what allows the evaporates elements to present itself in water with elevated concentrations. On the other hand, the carbonated mineral have been a weaker constant balance (Dolomite $(-17,02)$, Calcite $(-8,37)$, what produces a fast precipitation of chemical elements.

\section{CONCLUSION}

The interpretation of underground water chemical quality data in Ain Chabro-Hammamet plain is showed strong salinity of waters. Two dominant hydro chemical facies were observed: one calcicbicarbonate, near to the carbonated borders and the others were chlorinated soda, sulphated calcic, characterizing the center and the North of plain. The confrontation between the geological context and spatial distribution of chemical elements shows that, the origin of salinity is related mainly to the dissolution of three type's formations: 
- Evaporates formations associated with the Triassic outcrops exist in the Djebissa mountain and in the feet Belkfif mountain limit Northwest of plain

- Carbonated formations in the borders Southwest of plain

- Alluvial deposits in the center plain

Besides, the concentration and seasonal variation of the chemical elements is related to the precipitations, evaporation, and excess of pumping and irrigation effect. The diagram of $\mathrm{Ca}^{+2} /\left(\mathrm{HCO}_{3}{ }^{-}+\mathrm{SO}_{4}{ }^{-2}\right)-\mathrm{Na}^{+} / \mathrm{Cl}^{-}$ analysis shows that the phenomenon of basis exchange existing between the water of the groundwater and the geological formations which rich in clays.

The saturation index of the chemical minerals, shows the strong tendency of the carbonated minerals to precipitate (oversaturated), in relation to those evaporates mineral (under saturated), which allows the chemical elements to present with elevated concentrations.

In conclusion, we can propose to improve the groundwater chemical quality by two possibilities:

- The protection of groundwater against the anthropogenic surface pollutions (discharge wastes, wastewater, chemical fertilizer,...etc.)

- The application of artificial recharge technique by surface water with a good quality (noting that, this proposition is a part of our research in progress $)^{[10-13]}$

\section{ACKNOWLEDGMENT}

We would like to express our sincere gratitude and our thanks to Mr Vincent Vallès (Professor at the avignon hydrogeology laboratory), Mr Yves-Henri FAURE (Maitre of conference with LTHE, UJF, Grenoble), Mrs. Martine Lanson (Engineer LGIT, UJF, Grenoble), and Mr. Pierre-Yves Favarger (Institute F.A. Feral Geneva University, (Switzerland) for their helping in the realization of chemicals analysis.

\section{REFERENCES}

1. Boutaleb, S., L. Bouchaou, J. Mudry, Y. Hsissou, J. Mania and P. Chauve, 2000. Hydro geologic effect on the quality of water in the oued Issen watershed, western Upper Atlas Mountains, Morocco. Hydrogeol. J., 8: 230-236. DOI: 10.1007/S100400050009.
2. Chernet, T., Y. Travi, V. Valles, 2001. Mechanism of degradation of the quality of natural water in the lakes region of the Ethiopian rift valley. Water Ressourc., 35: 2819-2832. DOI: 10.1016/S00431354(01)00002-1.

3. Cheverry, C.1. and M. Robert, 1998. La dégradation des sols irrigués et de la ressource en eau : une menace pour l'avenir de l'agriculture et pour l'environnement des pays au sud de la Méditerranée? Etude et Gestion des Sols, 5, 4: 217-226. http://www.inra.fr/internet/ Hebergement/afes///pdf/EGS_5_4_CHEVERRY.p df?PHPSESSID=acfe40d4debe07151152b2.

4. Collin, J.J., 2004. Les Eaux Souterraines: Connaissance et Gestion. BRGM Édn., Hermann, ISBN-10: 2705664742, pp: 176.

5. De Marsily, G., 1981. Hydrogéologie quantitative. 1st Édn., Masson, ISBN: 2-225-75504-3, pp : 215.

6. De la Vaissiere, R., 2006. Etude de l'aquifère néogène du Bas-Dauphiné, Apports de la géochimie et des isotopes dans le fonctionnement hydrogéologique du bassin de Valence (Drome, SE de la France). Thése de Doctorat. University d'Avignon et des Pays de Vaucluse, pp : 278.

7. Hsissou, Y., L. Bouchaou, M. Krimissa and J. Mudry, 2001. Caractérisation de l'origine de la salinité des eaux de la nappe côtière d'Agadir (Maroc). Proceeding of the 1st International Conference on Salt Water and Coastal Aquifers, Monitoring, Modelling and Management, Apr. 2325. Essaouira, Morocco, pp: 1-11. http://www.olemiss.edu/sciencenet/saltnet/swica1/ hsissou-bouchaou-krimissa-paper.pdf.

8. Mehta, S., A.E. Fryar and J.L. Banner, 2000. Controls on the regional scale salinization of the Ogallala aquifer Southern high plains, texas, USA. Applied Geochem., 15: 849-864. http://cat.inist. $\mathrm{fr} /$ ?aModele $=$ afficheN\&cpsidt $=819154$.

9. Mohsen Jalali, 2007. Salinization of groundwater in arid and semi-arid zones: An example from Tajarak, western Iran. Environ. Geol., 52: 1133-1149. DOI: 10.1007/s00254-006-0551-3.

10. Remini, B., 2005. La problématique de l'eau en Algérie. 1st Edn., Office des Publications Universitaires, ISBN: 9961.0.0884.7, pp: 162.

11. Seghir, K., 2006. Perspectives de développement de la réalimentation artificielle des nappes souterraines dans les régions semi-arides: Cas de la nappe alluviale Ain-Chabro-Tébessa (Est Algérien). Algerian J. Arid Areas, Biskra, Algérie. 
12. Seghir,K. 2008. Impact de la sécheresse sur les ressources hydriques dans une région semi-aride. Caractérisation hydrogéologique,hydrochimique, bactériologique: Cas de la nappe alluviale Ain chabro-Hammamet (Nord Est Algérien). Réunion des Sciences de la Terre, du 21-24 Avril 2008, Nancy, France. http://www.rst2008.u-nancy.fr/
13. Seghir, K., 2008. La réalimentation artificielle des nappes phréatiques dans le Nord-Est Algérien. Visions croisées, Université Joseph Fourier, Grenoble, France, Mai 2008, pp: 8-9. 